\title{
Agreement between Students' and Their Instructors' Perceived Use of Good Practices in Undergraduate Education: Self-Reflections in Developmental Mathematics Classrooms
}

\author{
Amy G. Nabors ${ }^{a}$ and Linda Zientek
}

\begin{abstract}
Best practices in undergraduate classrooms have been identified. However research on the congruence between practices of faculty members and their students is lacking. In this study, confidence intervals were used as a mechanism to compare responses of three developmental mathematics instructors and their students on a subset of items from the Seven Principles Faculty and Student Inventories. Patterns observed in the confidence intervals indicated that, among the items studied, (a) there were consistent behaviors among students across classes and (b) students' and instructors' perceptions were not in agreement on several items. Future studies could compare all items or conduct observations to measure congruency.
\end{abstract}

Article info

\section{Introduction}

Self-assessment can lead to self-improvement (Ross \& Bruce, 2007); thus, the custom of having instructors and students self-assess their practices in the classroom is important. Even though the agreement between instructors and students' views of instructor practices has been compared (Negron-Morales et al., 1996), research that considers the agreement between the views of the practices utilized by students and those utilized by their instructors is lacking. This study was conducted in developmental mathematics courses that are comprised of students who have illustrated a need to improve their competency in mathematics before being allowed to enroll in college-level courses. Developmental education courses are a suitable population to study because of the recognized need to increase success rates in these courses (Bahr, 2008). The National Association of Developmental Education (NADE, n.d.), now known as the National

a Lone Star College, Department of Mathematics, amy.g.nabors@lonestar.edu, ORCID: 0000-0003-0530-9296

Corresponding author: Sam Houston State University, Department of Mathematics \& Statistics, lrzientek@shsu.edu ORCID: 0000-0001-9741-0257 
Organization for Student Success (NOSS), defined developmental education as “... a comprehensive process that focuses on the intellectual, social, and emotional growth and development of all students" and noted that it "includes, but is not limited to, tutoring, personal/career counseling, academic advisement, and coursework." (p. 1). We investigated the agreement between developmental mathematics instructor's responses to a subset of items from the Seven Principles of Good Practice in Undergraduate Education (Chickering \& Gamson, 1987) and their students' reflections of their practices on comparable items from the Seven Principles Student Inventory (Oberst, 1995).

\section{Self-Assessment}

Self-assessment is a tool used for self-improvement (Ross \& Bruce, 2007) that can come in the form of self-reflection or self-evaluation. According to Spinney (2017), selfreflection is the process of seeking insight about your behaviors, value, knowledge, and growth whereas self-evaluation is the process of studying your performance in an effort to improve skills. Self-reflection is considered an indispensable component of the learning process (Clarke et al., 2018). Dewey (1997) defined self-reflection in the context of education as an active, persistent, and careful consideration of a belief or knowledge. Dewey (1997) also elevated the area of self-reflection when he highlighted the impact it has on other areas such as critical thinking and personal and/or professional development.

Even though teaching evaluations of faculty members by their students or administrators has been a common practice, self-evaluation is also crucial to ongoing growth and development (see Nasser \& Fresko, 2002; Porter, 2017) and has been used as a tool for improving pedagogical practice (Ross \& Bruce, 2007). Teacher selfassessment can be defined as the "judgment of worth of one's understanding, and the identification of one's strengths and weaknesses with a view to improving one's teaching and learning outcomes" (Garofulo \& Trinter, 2013, p. 163). Teacher selfevaluation is a practice where teachers gather data on their own teaching effectiveness making it a form of self-reflection and any improvement is an indicator of teacher quality (Tursini, 2007). Ross and Bruce (2007) provided two situations where selfreflection does not lead to improvement, which are when (a) teachers give themselves a low appraisal that results in a depressing effect on teacher efficacy, and (b) teachers realize a need to change through self-appraisal but do not have the support to do so.

Students can also benefit from self-evaluation. This self-assessment process has the potential to impact student performance through heightened self-efficacy and enhanced intrinsic motivation (Majzub, 2013; Rolheiser \& Ross, 2001). Self-reflection by students helps establish communication with the teacher (Stallings \& Tascoine, 1996) and can be a tool to engage students in active learning (Olina \& Sullivan, 2004). Both studentfaculty contact and active learning are two of the principles of good practice promoted by Chickering and Gamson (1987).

Self-evaluation has the promise of having a positive effect for students. According to Stalling and Tascoine (1996), students' ability to do mathematics and become independent learners of mathematics can also be improved through selfassessment. Similar to teachers, students are also at risk of not benefiting from self- 
evaluation. Sometimes students do not fairly rate themselves because they find it hard to be honest about personal issues (Stallings \& Tascoine, 1996). If students perceive themselves to be unsuccessful, they can develop negative orientations toward learning. Zimmerman (2002) stated that teachers rarely ask student to self-evaluate their work or beliefs about learning, but need to encourage those activities to help students become self-regulated learners. Rolheiser and Ross (2001) claimed that self-evaluation is an amalgamation of self-judgement and self-reaction, that when properly incorporated, can contribute to an ascending cycle of better learning. They also claimed that students will evaluate their work regardless of teacher input, but teachers should teach them effective ways to appraise their work. Zimmerman (2002) defined self-judgment as comparing oneself against some standard and self-reaction as feelings of self-satisfaction that can fluctuate and influence the effectiveness of learning. In general, self-assessment is a good practice as it provides an opportunity for students and teachers to contemplate their actions and beliefs honestly.

\section{Conceptual Framework}

Efforts to improve undergraduate education led Chickering and Gamson (1987) to develop a list of seven principles that reflect previous good practices in undergraduate classrooms. The Seven Principles of Good Practice in Undergraduate Education served as a conceptual framework for this study and were based on research that spanned 50 years (Chickering \& Gamson, 1987). The seminal work by Chickering and Gamson (1987) has been a recognized framework for quality instruction in higher education. The seven principles were selected as the guiding framework for this study because the principles align well with the goals of developmental education, which focus on intellectual, social, and emotional development (NADE, n.d.). The principles express a philosophy of teaching and learning that is expansive enough to be relevant to (a) professional programs as well as liberal arts and (b) for all types of studentstraditional, non-traditional, well-prepared, and underprepared (Chickering \& Gamson, 1987). Table 1 provides a brief summary of the seven principles. 


\section{Table 1}

Overview of the Seven Principles of Good Practice (Chickering \& Gamson, 1987)

\begin{tabular}{ll}
\hline Principle & Description \\
\hline Student-Faculty contact & $\begin{array}{l}\text { Includes contact in and out of class; the most important factor for } \\
\text { student motivation }\end{array}$ \\
Cooperation & Good learning is social and collaborative, not competitive \\
Active Learning & $\begin{array}{l}\text { Appropriate feedback provides an opportunity for focused learning and } \\
\text { reflection }\end{array}$ \\
Prompt Feedback & $\begin{array}{l}\text { Student success is dependent on realistic allocation of time and } \\
\text { appropriate use of time }\end{array}$ \\
Time Management & $\begin{array}{l}\text { Expecting students to perform well is a self-fulfilling prophecy } \\
\text { High Expectations }\end{array}$ \\
Diverse Learning Styles & opportunities for all students
\end{tabular}

\section{Purpose of the Study}

In the United States, undergraduate students have been placed into developmental mathematics courses if they have been identified as needing remediation in mathematics. High failure rates in mathematics along with the need for many students to remediate skills (Bahr, 2008) has earned developmental mathematics the label of a barrier course for various academic programs. A challenge for the instructor is to improve students' proficiency skills and mathematical fluency with a group of students who often exhibit high levels of mathematics anxiety (Zientek et al., 2010). Smittle (2003) stated that successfully teaching developmental students requires teaching practices that are harmonious with practices of effective teaching such as the Seven Principles of Good Practice.

This study focused on Chickering and Gamson's (1987) seven principles for undergraduate education with a sample of developmental mathematics students and their instructors. Several research studies have examined instructors' use of the principles from the views of the students. For example, Fong and Zientek (2019) conducted a study with developmental mathematics students and determined that students' perceptions of their instructors' prompt feedback was a predictor of mathematics achievement. Cousins (2012) conducted a study with developmental English students and found that students perceived importance of the seven principles did not always align with the students' perceptions of their instructors use. Based on t-test results, Negron- Morales et al. (1996) determined there was disagreement between students and instructors on several instructors' instructional practices with a sample of undergraduate 
students. However, absent from the research, particularly in developmental mathematics, is students' self-reflection on their practices that promote the Chickering and Gamson's (1987) principles. Thus, the purpose of this study was to include the selfevaluations of both students and instructors on their individual use of the seven principles and then compare responses of students and their instructors. As noted by Howard and Whitaker (2011) "understanding more clearly how the perspectives of developmental mathematics students are formed and understanding what influences alter those perspectives can provide useful information for instructors who are committed to helping students achieve success" (p. 1). Comparing perspectives of students and instructors has the potential to inform practice and by extension enhance student outcomes.

\section{Research Questions}

The following two research questions were investigated:

1. To what extent do developmental mathematics students report they use practices aligned with the Chickering and Gamson's (1987) Seven Principles?

2. To what extent do faculty members and their developmental mathematics students agree regarding self-reported use of items identified as good practices in undergraduate education?

\section{Method}

\section{Research Design}

In this nonexperimental quantitative study, a survey design was used to collect data from developmental mathematics faculty and their students. The instructor survey requested information about the self-reported behaviors of faculty who taught developmental mathematics. The student survey requested information about the selfreported behaviors of students who were enrolled in developmental mathematics courses.

\section{Participants}

This study was conducted at a public 2-year community college because that is where the majority of developmental mathematics courses have been taught (Ganga et al., 2018). Participants were developmental mathematics instructors and their students from a large community college system in the Southwest. The convenience sample included participants who were easily recruited and willing to participate (Johnson \& Christensen, 2014). Instructors were recruited by email from the community college system. Participating instructors then invited their students to participate.

\section{Faculty}

Of the 79 mathematics faculty members that were invited to participate, 17 completed surveys and six faculty members (F1 - F6) agreed to distribute surveys to their students. 
Amy G. Nabors and Linda Zientek

One of those six faculty members was removed because he only taught college-level courses. Of the five participating faculty members who distributed the survey, four were part-time, two were female, and four held a master's degree. Average years of experience was 4.8 years and ranged from three to 10 years.

\section{Students}

The majority of the 67 students who completed the survey were female $(76.1 \%)$, under $25(66.2 \%)$, White $(50.7 \%)$, and spoke English as their first language $(75.4 \%) ; 31 \%$ were Hispanic. Full-time enrollment was not collected. Student responses were differentiated from faculty members responses by creating a code that corresponded to their instructor. For example, if the faculty's code in this study was F3, students' responses in F3's class were coded as S3.

\section{Response Rates}

Response rates were based on initial course enrollment. Because of the low response rates for Faculty 1 and 2 ( $n=1$ and $n=3$, respectively, our analyses focused on Faculty members 3, 4, and 5. Faculty 3 taught Math 0314/1314 and 0308 and had 23 student responses out of 28 enrolled for a $82 \%$ response rate. Faculty 4 taught Math 0232/1332 and had 16 student responses out of 24 enrolled for a response rate of $66.7 \%$ response rate. Faculty 5 taught Math 0308 and 0314 and had 17 responses out of 53 enrolled for a response rate of $32 \%$.

\section{Course Structure}

Three levels of developmental mathematics were offered during the 2017-2018 academic year. In accordance with the state legislature requirement that post-secondary institutions shift from stand-alone developmental courses to co-requisite courses, the college offered two stand-alone developmental courses (Math 0308 and Math 0310) and four co-requisite developmental courses (Math 0106, 0232, 0314, and 0324). Corequisite developmental courses were linked (i.e., paired) to a corresponding creditbearing course, except for 0106 which linked the lowest and middle level developmental courses. Math 0308 covered elementary algebra. Math 0310 covered intermediate algebra skills and was a terminal level of mathematics required for a few of the college programs. Math 0314 also covered intermediate algebra skills and provided support for students concurrently enrolled in Math 1314 (College Algebra). Math 0232 provided support and covers pre-requisite skills needed for Math 1332 (Math for Liberal Arts).

\section{Instrumentation}

\section{Faculty Inventory}

Faculty members completed a modified Faculty Inventory (Chickering et al., 1991). The original inventory contained seven sections with 10 questions each measured on a 5point Likert scale with "1" equals strongly disagree and "5" equals strongly agree. The 
seven sections corresponded with the Seven Principles of Good Practice for Undergraduate Education (Chickering \& Gamson, 1987). Permission was given to modify the inventory; some items were removed. Items included in this study are provided in the Appendix. The Faculty Inventory was designed to be a self-evaluation tool that provided a method for faculty to reflect on their classroom behaviors, but was not intended to be a tool for evaluating individual faculty members (Chickering et al., 1991). The purpose of the inventory was not violated in this study because individual faculty members were not evaluated but the results were used to describe the practices of developmental mathematics instructors. As noted by Chickering et al. (1991), it is easy for participants to generate a positive report; thus, the value of the inventory is centered on the honesty of respondents. The faculty sample size $(n=3)$ was too small to report Cronbach's alpha $(\alpha)$ reliability coefficients. However, reliability coefficients in previous studies were reported at the acceptable level (i.e., $\alpha \geq .7$ ) for the entire instrument ( $\alpha=.94$; Bangert, 2004) and for each construct except SF ( $\alpha=.516$; Smith, $2014)$. Instructors also were asked to report their gender, age (" 0 " $=<25$ years; " 1 " = $25+$ years), and teaching experience ("0" $=0-3$ years; " $1 "=4-10$ years; " $2 "=>10$ years).

\section{Student Inventory}

A student inventory for the Seven Principles was outlined by a small group in 1990 with the intention that self-reflection would facilitate behavior change to enhance learning (Oberst, 1995). That group drafted a student inventory and began testing but never completed the testing or published the inventory. As a student, Oberst procured the development of the inventory. The completed Seven Principles Student Inventory was finalized, adopted, and distributed by the Seven Principles Resource Center at Winona State University, which is no longer in operation (Oberst, 1995). Oberst referred to "diverse learning styles" as "multiple approaches to learning". For this study, to keep student and faculty data labels consistent, both will be referred to as "respect diversity". Higher scores on the instrument indicate preferred practices. Oberst (1995) conducted a factor analysis on the inventory and reported seven factors that almost completely aligned with the Seven Principles, but the principle of "high expectations" did not load a distinct component and the principle of "active learning" split into two components. Oberst (1995) reported Cronbach's alpha coefficients that ranged from .70 to .81 for the constructs and .935 for the entire instrument. In this study, we only included items that we believed matched well with the faculty inventory. Because reliability coefficients should not be reported for constructs with fewer than three items (Thompson, 2003), Cronbach's alpha was not reported for the two constructs in in our study that only had two items (i.e., Prompt Feedback and High Expectations). For the remaining subset of items investigated, Cronbach's alpha was acceptable for the entire set of items $(\alpha=.929)$ and the constructs $\operatorname{sCAS}(\alpha=.858)$, sAL $(\alpha=.846), \operatorname{sTM}(\alpha=.755)$, and $\operatorname{sRD}(\alpha=.707)$, but not for sSFC $(\alpha=.527)$. See the Appendix for abbreviations. 


\section{Procedures}

After IRB approval, faculty members who indicated they would participate were asked to complete the teacher survey and were asked to distribute the student survey. Participants had to give consent before they were allowed to access the survey. Data collection occurred within a two-week period during the middle of the semester. This time period was chosen because students' practices would have been established and students would not be experiencing the stress of finals if this had been conducted close to the end of the semester. Participants were offered an opportunity to enter their email address into a drawing for a gift card.

\section{Data Analysis}

To explore agreement between faculty members and their students, 95\% confidence intervals for the mean were interpreted. There are many benefits to interpreting confidence intervals (see Cumming, 2011; Zientek et al., 2010), which include a plausible range of values, precision as measured by the width of the confidence interval, and the ability to synthesize findings (see Zientek et al., 2012). Cumming and Finch (2001) noted that the confidence interval "width reflects a number of aspects of the precision of a study, including the amount of variability in the population, the sample size and thus sampling error, and the amount of error in the dependent variable" ( $p$. 564). Confidence intervals provide a visual of these aspects. For example, overlapping confidence intervals that are wide (i.e., large sampling error) are not as interesting as comparing confidence intervals that are narrow (i.e., smaller sampling error). Despite the fact that the reporting of confidence intervals has been recommended (American Psychological Association, 2020; Wilkinson \& the Task Force on Statistics Inference, 1999), reporting of CIs in research often has been lacking (Hopkins et al., 2019; Zientek et al., 2008). In our study, confidence intervals were used to compare response students' rating across classes.

\section{Results}

The matched student and faculty inventory items used in this study are included in the Appendix. Table 2 provides the descriptive statistics for students' responses by each item disaggregated by class (i.e. S3, S4, and S5). Faculty members' ratings for each matched item were also included (i.e., F3, F4, and F5). Stars represent faulty members' ratings on corresponding items designated in Table 2. 


\section{Table 2}

Student and Faculty Inventory Item Ratings

\begin{tabular}{|c|c|c|c|c|c|c|c|c|c|}
\hline $\begin{array}{c}\text { Items } \\
\text { FAC/STU } \\
\end{array}$ & $\mathrm{F} 3$ & $\begin{array}{l}\mathrm{S} 3 \\
M \\
\end{array}$ & $\begin{array}{r}n=23 \\
S D\end{array}$ & $\mathrm{~F} 4$ & $\begin{array}{r}\mathrm{S} 4 \\
M \\
\end{array}$ & $\begin{array}{r}n=16 \\
S D\end{array}$ & F5 & $\begin{array}{l}\text { S5 } \\
M \\
\end{array}$ & $\begin{array}{r}n=17 \\
S D\end{array}$ \\
\hline tSFC1/sSFC3 & 5 & 2.74 & 1.176 & 5 & 3.25 & 1.238 & 5 & 2.94 & 1.391 \\
\hline tSCF2/sSFC5 & 3 & 2.04 & 1.186 & 5 & 2.31 & 1.448 & 4 & 3.18 & 1.334 \\
\hline $\mathrm{tSFC} 4 / \mathrm{sSFC} 1$ & 4 & 2.74 & 1.214 & 5 & 2.94 & 1.340 & 3 & 3.42 & 1.71 \\
\hline tCAS1/sCAS1 & 3 & 3.26 & 1.356 & 4 & 3.06 & 1.289 & 1 & 2.82 & 1.38 \\
\hline $\mathrm{tCAS} 2 / \mathrm{sCAS} 2$ & 4 & 2.87 & 1.604 & 3 & 2.25 & 1.291 & 3 & 2.59 & 1.417 \\
\hline $\mathrm{tCAS} 4 / \mathrm{sCAS} 4$ & 4 & 3.61 & 1.438 & 5 & 4.00 & 1.095 & 2 & 3.41 & 1.417 \\
\hline tCAS5/sCAS5 & 3 & 3.35 & 1.584 & 4 & 3.31 & 1.302 & 2 & 3.59 & 1.583 \\
\hline tAL2/tAL2 & 5 & 2.78 & 1.043 & 4 & 3.19 & 1.167 & 1 & 2.88 & 2.95 \\
\hline tAL3/sAL3 & 3 & 2.35 & 1.265 & 4 & 2.81 & 1.515 & 1 & 3.47 & 1.231 \\
\hline tAL4/sAL4 & 4 & 2.61 & 1.305 & 5 & 3.06 & 1.237 & 2 & 3.35 & 1.412 \\
\hline tPF4/sPF2 & 5 & 2.74 & 1.356 & 3 & 3.56 & 1.365 & 2 & 3.65 & 1.32 \\
\hline $\mathrm{tPF} 5 / \mathrm{sPF} 1$ & 5 & 3.52 & 1.442 & 4 & 4.13 & 1.088 & 3 & 4.12 & 1.166 \\
\hline tTM1/sTM1 & 4 & 2.87 & 1.217 & 5 & 3.06 & 1.063 & 5 & 3.35 & 1.222 \\
\hline tTM2/sTM4 & 5 & 2.57 & 1.199 & 5 & 3.25 & 1.065 & 5 & 3.65 & 1.115 \\
\hline tTM3/sTM5 & 5 & 4.35 & 1.027 & 4 & 4.69 & 0.479 & 5 & 4.00 & 1.369 \\
\hline tTM5/sTM6 & 5 & 3.26 & 1.251 & 4 & 3.24 & 1.251 & 4 & 3.75 & 1.446 \\
\hline tHE2/sHE5 & 5 & 3.13 & 1.254 & 5 & 3.56 & 1.094 & 4 & 3.41 & 0.87 \\
\hline tHE3/sHE2 & 5 & 3.13 & 1.27 & 5 & 3.06 & 1.340 & 3 & 3.82 & 1.237 \\
\hline tRD2/sRD1 & 3 & 3.78 & 1.476 & 5 & 3.69 & 1.702 & 4 & 3.59 & 1.805 \\
\hline tRD3/sRD2 & 2 & 2.96 & 1.296 & 4 & 3.81 & 1.109 & 2 & 3.82 & 1.185 \\
\hline tRD4/sRD5 & 4 & 3.52 & 1.275 & 4 & 3.50 & 1.211 & 5 & 3.94 & 1.144 \\
\hline
\end{tabular}

\section{Students' Ratings across Classes}

Figures 1 and 2 provide a graphical representation of the $95 \%$ confidence intervals of the mean for each item disaggregated by faculty member. Incongruence appeared for sTM4. For the student item sTM4, confidence intervals of means did not overlap for two of the three classes (i.e., F3 and F5). While congruence as measured by overlapping 
intervals was met for all other items except for sTM4, the upper and lower limits of the confidence intervals were very close on several items. For sAL3, the upper and lower limits of the confidence intervals were close in value (i.e, upper limit 2.89 for class F3 and lower limit 2.84 for class F5). On sSFC5, the overlap was minimal for classes F3 and F5; the upper limit was 2.56 for class F3 and the lower limit was 2.49 for class F5. For sRD2, the upper limit was 3.52 for class F3 and the lower limits were 3.22 and 3.21 for classes F4 and F5, respectively. Thus, the overlap was from the range 3.21 to 3.52. For the remaining construct items except for possibly sPF2 that had a somewhat small overlap, congruence was unquestionable. For student responses, a large proportion of the width of the confidence intervals overlapped for all of the items linked to Cooperation among Students (sCAS), Prompt Feedback (sPF) and High Expectation (sHE).

\section{Figure 1}

The 95\% Confidence Intervals of the Mean for Students' Responses on Four Constructs Compared to Their Instructors Responses
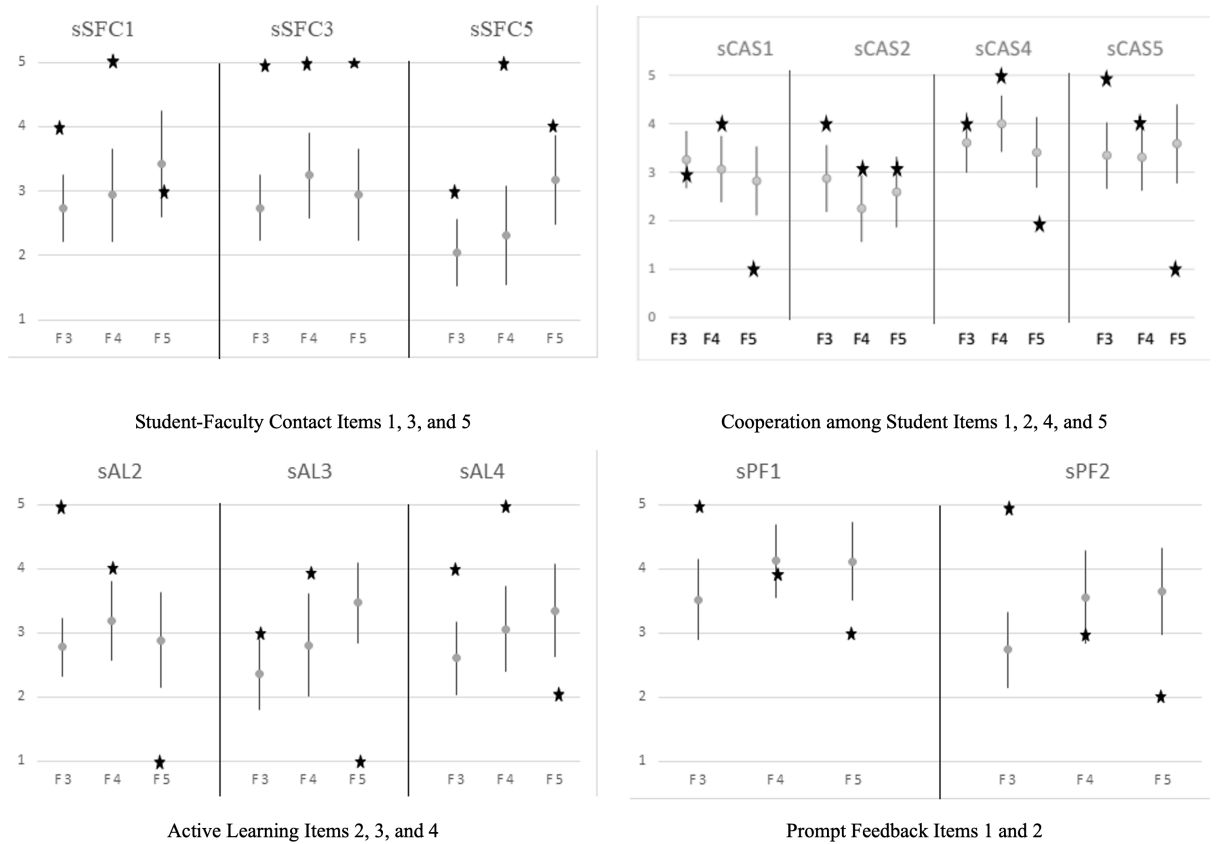

Note. Stars are faculty members responses on corresponding items designated in Table 2. 


\section{Figure 2}

The 95\% Confidence Intervals of the Mean for Students' Responses on Three Constructs Compared to Their Instructors Responses

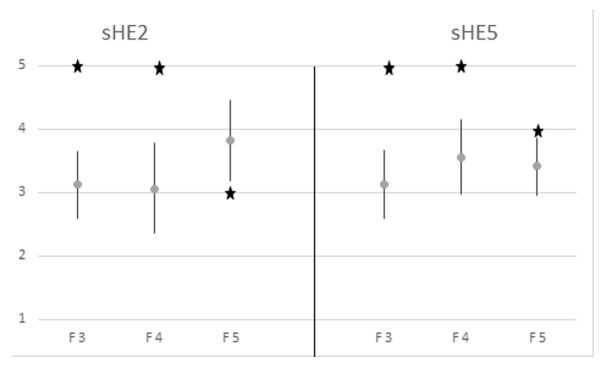

High Expectations Items 2 and 5

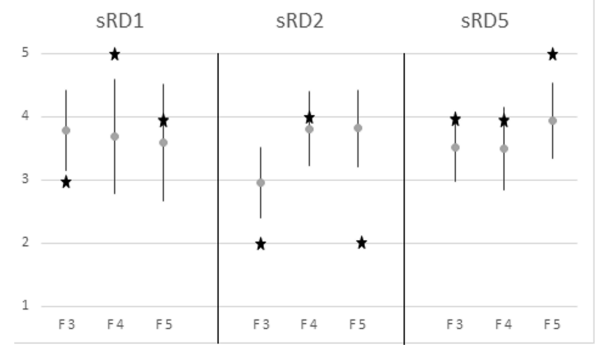

Respect Diversity Items 1, 2, and 5

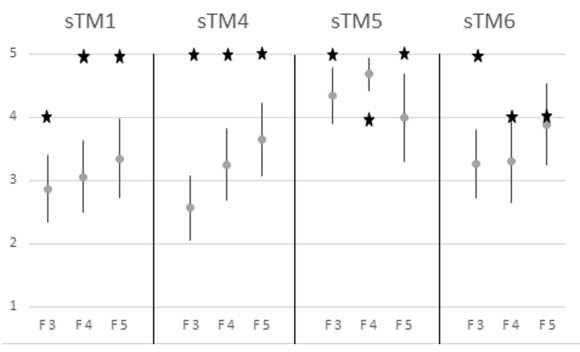

Time Management Items 1, 4, 5, and 6

Note. Stars are faculty members responses on corresponding items designated in Table 2 .

\section{Student-Faculty Congruency}

If a faculty member's rating was inside their respective students' confidence interval for the mean, we considered this student-faculty congruence. Confidence intervals on the 21 items disaggregated by faculty members in Figures 1 and 2 indicated faculty member 3 (F3) was the least congruent with students. F3 had congruency on only three items, sCAS1, sCAS4, and sRD5. Faculty member 4 (F4) was congruent with students on five items, sCAS5, sPF1, sPF2, sRD2, and sRD5. Faculty member 5 (F5) was congruent with students on four items, sSFC1, sCAS2, sTM6, and sRD1.

\section{Discussion}

Because failure rates in developmental mathematics classrooms have been high, more measures need to be taken to increase student success (Bahr, 2008). The role of the faculty members is critical in helping students achieve their academic goals (Howard $\&$ Whitaker, 2011). However, improvements in instruction will require that instructors are willing to make changes (Nasser \& Fresko, 2002). The student also needs to consider their behaviors. A first step towards modifying practices is self-evaluation. 
Inventories such as the Seven Principles of Good Practice in Undergraduate Education (Chickering \& Gamson, 1987) and Seven Principles Student Inventory (Oberst, 1995) can serve as self-reflection tools to help instructors and students gain insight into their practices. Furthermore, determining congruency between students' and faculty members' perspectives can help instructors determine which practices are in agreement or disagreement with their students' beliefs. This study used confidence intervals as a mechanism to compare students and faculty members' responses because confidence intervals provide both point estimates (e.g. means) and confidence bands around these estimates (Zientek et al., 2010). Our findings indicate that there is (a) student agreement across classes and (b) student-faculty differences across many items, but those differences might be attributed to high ratings of faculty members.

\section{Students' Ratings Across Classes}

An inspection of mean scores and confidence intervals across classes revealed that students' ratings of their practices tended to be consistent across classes for most items. However, responses on a few items did not follow that pattern. Explanations for differences were beyond the scope of this study and should be explored in future studies.

\section{Incongruent Ratings}

The student time management item (sTM4) that pertained to students' ability to maintain a study schedule was incongruent for two classes (i.e., F3 and F5 classrooms). Zimmerman (2002) noted that self-regulated learning has been explained as "selfgenerated thoughts, feelings, behaviors that are oriented to attaining goals" (p. 65) and the ability to manage one's time efficiently is a component skill of self-regulated learning. Future research could examine multiple variables that influence students' ability to manage their study time.

\section{Narrowly Congruent}

More research needs to be conducted on relating mathematics to the real world. Instructors need to continue to find resources that can help students relate the mathematics content to activities outside the classroom (sAL3), particularly given the lower mean scores as seen in Table 2 for two of the classes. The upper bound of the confidence internal for class F3 was close to the lower bound for class F5 on item sAL3. A larger sample size might have resulted in non-overlapping confidence intervals for the one instructor because confidence intervals calculated from small sample sizes tend to have higher standard errors and wider confidence intervals compared to studies with large sample sizes. Similarly, congruence was barely achieved for the student item in two of the classes for sRD2 that referred to adjusting learning habits to be attuned with the teachers' practices. Encouragingly, average ratings were on the more positive side for the two congruent classes. For sSFC5, the overlap was relatively small with low means and medians, which suggests students were not looking for opportunities that would enable them to get to know their instructors' professional responsibilities. 


\section{Congruent Ratings}

For all other student items, confidence intervals illustrated students' responses were unquestionably congruent across the three classes. Overlapping confidence intervals indicated that, for all three classes, each of the items in sCAS had similar patterns of behavior in reference to how they familiarize themselves and work with their classmates. In this study, students less frequently made efforts to get to know their classmates or form study groups, but more frequently assisted other students who asked for help and praised them when they did good work. Those practices might be influenced by the diverse population of community colleges that is comprised of commuters, part-time students, and students with full-time jobs.

On the two prompt feedback items (sPF), the confidence intervals overlapped across the classes (i.e., congruent). Except for students in F3 on sPF2, students tended to be positive on prompt feedback items. They were more apt to review their feedback, if they received it, compared to talking over feedback with their professors as quickly as possible. Students were congruent across all classes on both high expectation items (sHE), as determined by confidence intervals. They rated that they occasionally attempted to attain information about their instructor's goals and occasionally thoughtfully considered the balance between the actions they do to help them learn and the things they do to attain a grade.

\section{Student-Faculty Comparisons}

\section{Respect Diversity}

Collectively, instructors were attempting to address underrepresented population in their courses (tRD4) and student responses were somewhat positive on the corresponding student item (sRD5). However, instructor responses varied for the other two Respect Diversity items. At least two of the three faculty members reported that they seldom integrated teaching activities designed to address a wide range of students (i.e., item tRD3). As Cousins (2012) stated, "all students can benefit from multiple ways of processing new information and expressing what they have learned" (p. 13). Our conclusion is that the inconsistencies between faculty and students for two of the classes suggests the teacher item tRD3 might not match to the student item sRD2 that pertained to adjusting learning habits.

\section{High Expectations and Active Learning Principles}

Students and their respective instructor were not congruent on items related to High Expectations or Active Learning principles. Two faculty members indicated that at the beginning of the semester they very often provided their expectations orally and in writing. However, on average, their students were in the middle of the scale for obtaining information about their instructor's goals. Instructors might consider periodically administering a quiz to determine if students understand the expectations or goals for the course. Differences on tAL2 and sAL2 might be attributed to an item 
misalignment. Teacher item tAL2 relates to the understanding similarity and differences of mathematical concepts, which has been well-documented as an important learning principle (Cafarella, 2014; Hendrix, 1996). However, summarizations by instructors did not seem to translate into students questioning the assumptions of the mathematical material (sAL2). Future research needs to look into what assumptions students are questioning in their mathematics courses, particularly a group of students who struggle in mathematics. Regardless, students were congruent across classes and instructors varied. Finally, providing concrete, real-world problems did not seem to be congruent with students deciding to seek out real-world situations for their mathematics. This suggests that instructors need to also direct students to seek out those experiences, possibly as an assignment.

\section{Student-Faculty Contact}

All three faculty members reportedly encouraged students to ask questions, but students indicated they were less likely to question something an instructor said if they disagreed with it. This difference might be related to the population of students and their comfort level with mathematics (see Zientek et al., 2010). Developmental mathematics students often exhibit high levels of mathematics anxiety and, thus, might be more reluctant to question a professor about mathematics content. Also, we hypothesize that those students might not have enough confidence in mathematics to feel comfortable questioning their instructors. For the most part, students were not seeking to find out about their teachers on a professional or personal level and faculty were varied on whether or not they shared experiences and attitudes.

\section{Time Management}

All three faculty members rated time management items as a four or a five, and students indicated that they regularly attended class. Those responses were encouraging because research has suggested that attendance is one of the best predictors of student success (Zientek et al., 2013) and explaining consequences for not-attending might encourage attendance (Albert et al., 2018). However, students rated their practice lower than their instructors on two of the three remaining constructs. Thus, more explorations need to be conducted to determine how to increase prompt completion of assignments and maintain regular study schedules.

\section{Prompt Feedback}

On the two prompt feedback items that were examined for congruency, results varied among faculty members. Two instructors indicated that they often or very often provided written comments on students' assignments about their strengths and weaknesses but only F4 was congruent with their students' responses (sPF1). Future studies should explore the relationship between the extent to which students promptly talked with their instructors when material was not clear and instructors request to schedule meetings. One instructor indicated that they very often asked students to schedule a meeting with them to discuss their work but only F4 was congruent with 
student responses (sPF2). Even though grading mathematics tests often requires grading for correct or incorrect answers along with partial credit for incorrect responses, identifying students' strengths aligns with appropriate praise that can help improve their self-efficacy (Usher \& Pajares, 2006). It is possible that two of the instructors did not schedule meetings because the instructors met with students immediately before or after class or even during class time. Arriving to class early is a positive practice that can provide students with opportunities to meet with their instructors without scheduling separate meetings.

\section{Cooperation among Students}

Of all of the principles, the responses for Cooperation among Students is the most difficult to synthesize. While some congruencies existed, F5 provided low ratings on three of the CAS items. Instructors and students were more congruent on sCAS2 and the corresponding tCAS2, which both dealt with studying together. However, the ratings were lower than desired and might relate to the population of part-time students and faculty understand that students are not on campus very often. However, in today's world of technology, students can study together in various locations and studying together has been shown to be beneficial to student success (Tinto, 2012; Dinman, 1996). Interestingly, even though one instructor did not encourage peer-to-peer praise, the students in that classroom did not differ from the other classrooms on whether or not they praised students for work well done.

\section{Additional Observations}

It is unknown why F3 was not congruent with students on many items. However, F3's responses regarding encouraging students to learn about each other, work together on difficult concepts, and integrate knowledge of underrepresented populations was similar to the frequency at which students reported participating in those activities. Even though students' responses appeared congruent across classes for most items, many confidence interval bands tended to exclude extreme values. Thus, some congruent responses might be related to when faculty members rated their use of practices as a three or a four.

\section{Limitations}

The primary limitation of this study was the small number of faculty members who agreed to participate. The demographics of this college limits the generalizability of the results. In addition, while self-reports are an efficient way to collect data, responses can be skewed by a person being overly critical or overly generous on their self-examination of their classroom practices.

\section{Implications and Future Research}

Self-reflections can serve as a tool for improving teaching practices and learning. Yet, students' self-reflection in comparison with instructors' practices are seldom made. We examined the congruency of students and faculty members' ratings of a subset of items 
that were matched from the Seven Principles of Good Practice as measured by the Faculty Inventory (Chickering \& Gamson, 1991) and Student Inventory (Oberst, 1995). Results indicated students ratings were somewhat consistent across classes for most items, which suggests that the differences in practices were not necessarily tied to the developmental mathematics instructors' approaches but possibly practices ingrained in the student. Thus, our findings suggest that more research needs to focus on the best methods to help alter developmental mathematics students' learning habits. Furthermore, cooperation among students needs to be encouraged and redesigned to include technology, particularly for a population of students who are often part-time and commute. Advisors and instructors need to educate students about and on the available technology that can be used to create online study communities. Encouragingly, students understood the importance of classroom attendance. Future research should consider a qualitative examination of the behaviors teachers are implementing to promote the seven principles using a larger sample of faculty members and students and examining other variables that influence student behavior. Additionally, our results may inform the design of professional development activities for faculty or interventions for struggling students.

\section{Conclusion}

Systematic changes in the classroom can be improved by understanding classroom practices through the lens of students and their instructors. The reality supports the assertion that instructors and students should self-reflect on their use of the seven principles (Chickering \& Gamson, 1987; Oberst, 1995). Thus, as the educational community reconsiders the developmental education course model, self-reflection needs to be considered along with measures that help students adopt effective learning habits at the earliest possible time and prior to entering college-level courses.

\section{Authors' Note}

This study was approved by Sam Houston State University Research Ethics Committee (Approval no. 2018-22).

\section{References}

Albert, J., Zientek, L. R., \& Manage, A. (2018). Attendance: A case-study in developmental mathematics classrooms. Journal of College Reading and Learning, 48(3), 175-188. https://doi.org/10.1080/10790195.2018.1472941

American Psychological Association. (2020). Publication manual of the American Psychological Association (7th ed.). Author.

Bahr, P. R. (2008). Does mathematics remediation work?: A comparative analysis of academic attainment among community college students. Research in Higher Education, 49(5), 420-450. https://doi.org/10.1007/s11162-008-9089-4

Bangert, A. W. (2004). The seven principles of good practice: A framework for evaluating online teaching. The International Higher Education, 7(3), 217-232. https://doi.org/10.1016/j.iheduc.2004.06.003 
Cafarella, B. V. (2014) Exploring best practices in developmental math. Research \& Teaching in Developmental Education, 30(2), 35-64.

Chickering, A., \& Gamson, Z. (1987). Seven principles of good practice in undergraduate education. AAHE Bulletin, 30(7), 3-7.

Chickering A. W., Gamson, Z. F., \& Barsi, L. M. (1991). Seven principles of good practice in undergraduate education faculty inventory. In A. W. Chickering \& Z. F. Gamson (Eds.), Applying the seven principles for good practice in undergraduate education (pp. 71-85). Josey-Bass.

Clarke, S., Arnab, S. Morini, L., \& Heywood, L. (2018). Remixing dungeons and dragons: A playful approach to student self-reflection. Proceedings of the European Conference on Games Based Learning (pp. 872-875).

Cousins, C. L. (2012). A case study of community college students' perceptions of linked courses instructors' use of Chickering and Gamson's (1987). (UMI No. 3508225). (Ed.D. Dissertation, University of Hartford). ProQuest Dissertations and Theses Database.

Cumming, G. (2011). Understanding the new statistics: Effect sizes, confidence intervals, and meta-analyses. Routledge.

Cumming, G., \& Finch, S. (2001). A primer on the understanding, use, and calculation of confidence intervals that are based on central and noncentral distributions. Educational and Psychological Measurement, 61(4), 532-574. https://doi.org/10.1177/0013164401614002

Dewey, J. (1997). How we think. Dover Publications, INC. Mineola, New York.

Dinman, S. M. (1996). What college teachers need to know. In R. J. Menges \& M. Weimer (Eds.), Teaching on solid ground (pp. 297-314). Jossey-Bass.

Fong, C. J., \& Zientek, L. R. (2019). Instructional practices in developmental mathematics: A multilevel analysis of community college student perceptions. Journal of College Reading and Learning, 49(1), 35-52. https://doi.org/10.1080/10790195.2018.1514283

Ganga, E., Mazzariello, A., \& Edgecombe, N. (2018). Developmental education: An introduction for policymakers. Center for the Analysis of Postsecondary Readiness.

https://www.ecs.org/developmental-education-an-introduction-for-policymakers/

Garofalo, J., \& Trinter, C. (2013). Using simulations to foster preservice mathematics teachers' self-assessment, learning, and reflections on teaching. Mathematics Teacher Educator, 1(2), 162-171. https://doi.org/10.5951/mathteaceduc.1.2.0162

Hendrix, J. C. (1996). Cooperative learning: Building a democratic community. Clearing House, 69(6), 333-336. https://doi.org/10.1080/00098655.1996.10114333

Hopkins, Z. H., Moreno, C., \& Secrest, A. M. (2019). Lack of confidence interval reporting in dermatology: A call to action. British Journal of Dermatology. 180(4), 910-915. https://doi.org/10.1111/bjd.17126

Howard, L., \& Whitaker, M. (2011). Unsuccessful and successful mathematics learning: Developmental students' perceptions. Journal of Developmental Education, 35(2), 1-16. 
Johnson, R. B., \& Christensen, L. (2014). Educational research: Quantitative, qualitative, and mixed approaches (5th ed.). Sage.

Majzub, R. M. (2013). Teacher trainees' self-evaluation during teaching practicum. Procedia-Social and Behavioral Sciences, 102(22), 195-203. https://doi.org/10.1016/j.sbspro.2013.10.733

National Association of Developmental Education (n.d.). NADE-Mission, vision, and goals.

Nasser, F., \& Fresko, B. (2002). Faculty views of student evaluation of college teaching. Assessment \& Evaluation in Higher Education, 27(2), 187-198. https://doi.org/10.1080/02602930220128751

Negron-Morales, P.,Vazquez-Rodriquez, I., \& Leon-Lozada, A. D. (1996). Good practices in undergraduate education from the students' and faculty's view: Consensus or disagreement (ED397729). ERIC.

Oberst, J. E. (1995). Seven principles student inventory: An indicator of success? (UMI No. 9544938). (Doctoral dissertation, Syracuse University). ProQuest Dissertations and Theses Database.

Olina, Z., \& Sullivan, H. J. (2004) Student self-evaluation, teacher evaluation, and learner performance. Educational Technology Research and Development, 52(3), 5-22. https://doi.org/10.1007/BF02504672

Porter, J. (2017). Why you should make time for self-reflection (Even if you hate doing it). Harvard Business Review. https://hbr.org/2017/03/why-you-should-maketime-for-self-reflection-even-if-you-hate-doing-it

Rolheiser, C., \& Ross, J. A. (2001). Student self-evaluation: What research says and what practice shows. In R. D. Small, \& A. Thomas (Eds.), Plain talk about kids (pp. 43-57). Center for Development and Learning.

Ross, J. A., \& Bruce, C. A. (2007). Teacher self-assessment: A mechanism for facilitating professional growth. Teaching and Teacher Education, 23(2), 146-159. https://doi.org/10.1016/j.tate.2006.04.035

Smith, E. G. (2014). Faculty integration of technology in undergraduate courses at private colleges and universities. Unpublished doctoral dissertation. https://dc.etsu.edu/etd/2444

Smittle, P. (2003). Principles for effective teaching in developmental education. Journal of Developmental Education 26(3), 10-12, 14, 16.

Spinney, K. (2017). The importance of self-evaluation and self-reflection throughout the year (not just at performance review time). Retrieved from https://katherinespinney.com/importance-selfreflection-selfevaluationthroughout-year-not-just-performance-review-time/

Stallings, V., \& Tascoine, C. (1996). Student self-assessment and self-evaluation. The Mathematics Teacher, 89(7), 548-554.

Thompson, B. (2003). Score reliability: Contemporary thinking on reliability issues. Sage.

Tinto, V. (2012). Completing college: Rethinking institutional action. The University of Chicago Press.

Tursini, U. (2017). Exploring changes in teachers' instructional practice through selfevaluation as a meditational activity: A case study. Journal of Language Teaching and Research, 8(3), 556-564. https://doi.org/10.17507/jltr.0803.14 
Usher, E. L., \& Pajares, F. (2006). Inviting confidence in school: Invitations as a critical source of the academic self-efficacy beliefs of entering middle school students. Journal of Invitational Theory and Practice, 12, 7-16.

Wilkinson, L., \& Task Force on Statistical Inference. (1999). Statistical methods in psychology journals: Guidelines and explanations. American Psychologist, 54(8), 594-604. https://doi.org/10.1037/0003-066X.54.8.594

Zientek, L. R., Capraro, M. M., \& Capraro, R. M. (2008). Reporting practices in quantitative teacher education research: One look at the evidence cited in the AERA panel report. Educational Researcher, 37(4), 208-216. https://doi.org/10.3102/0013189X08319762

Zientek, L. R., Ozel, Z. E. Y., Fong, C. J., \& Griffin, M. (2013). Student success in developmental mathematics courses. Community College Journal of Research and Practice, 37(12), 990-1010. https://doi.org/10.1080/10668926.2010.491993

Zientek, L. R., Yetkiner Ozel, Z. E., Ozel, S., \& Allen, J. (2012). Reporting confidence intervals and effect sizes: Collecting the evidence. Career and Technical Education Research, 37(3), 277-295.

Zientek, L. R., Yetkiner, Z. E., \& Thompson, B. (2010). Characterizing the mathematics anxiety literature using confidence intervals as a literature review mechanism. The Journal of Educational Research, 103(6), 424-438. https://doi.org/10.1080/00220670903383093

Zimmerman, B. J. (2002). Becoming a self-regulated learner: An overview. Theory into Practice, 41(2), 64-70. https://doi.org/10.1207/s15430421tip4102_2

\section{Lisans Eğitiminde İyi Uygulamaların Kullanımına İlişkin Öğrencilerin ve Öğretim Üyelerinin Algıları Arasındaki Uyum: Gelişimsel Matematik Sınıflarında Öz-Yansitma}

$\ddot{O} \mathbf{z}$

Lisans düzeyinde en iyi uygulamalar bellidir. Ancak öğretim üyeleri ile öğrencilerin bu uygulamaların eğitimde kullanımına ilişkin algıları arasındaki uyumsuzluk yeterince araştırılmamıştır. Bu çalışmada, Ö̆gretim Üyesi ve Ö̆grenciler için Yedi İlke Envanteri'nden bir grup maddeye üç gelişimsel matematik ögretim elemanı ve ögrencilerinin verdiği yanıtları karşılaştırmak için güven aralıkları mekanizması kullanılmıştır. Güven aralıklarında gözlemlenen örüntüler, incelenen maddeler açısından (a) sinıf düzeyinde ögrenciler arasında tutarlı davranışlar olduğunu ve (b) öğrencilerin ve öğretim elemanlarının algılarının birkaç madde üzerinde ayrıştığını göstermiştir. Gelecekteki çalışmalar tüm maddeleri karşılaştırabilir veya uyumluluğu ölçmek için gözlemler yapabilir.

Anahtar sözcükler: İyi uygulamanın yedi ilkesi, gelişimsel matematik, öğrenci-öğretim üyesi karşılaştırması, güven aralıklarl 


\begin{tabular}{|c|c|}
\hline \multicolumn{2}{|c|}{ Appendix } \\
\hline $\begin{array}{l}\text { FACULTY INVENTORY } \\
\text { (Chickering \& Gamson, 1987) }\end{array}$ & $\begin{array}{l}\text { STUDENT INVENTORY } \\
\text { (Oberst, 1995) }\end{array}$ \\
\hline \multicolumn{2}{|c|}{ Student-Faculty Contact } \\
\hline tSFC1 I encourage students to ask questions. & $\begin{array}{l}\text { sSFC3 I question my professor when I disagree with what is } \\
\text { said. }\end{array}$ \\
\hline $\begin{array}{l}\text { tSFC2 I share my past experiences, attitudes, and values with } \\
\text { students. }\end{array}$ & $\begin{array}{l}\text { sSFC5 I find out about my professors- what else they teach, } \\
\text { areas of expertise, and other areas of interest. }\end{array}$ \\
\hline tSFC4 I serve as a mentor or informal advisor to students. & $\begin{array}{l}\text { sSFC1 I look for opportunities to develop informal } \\
\text { relationships with one or more of my professors. }\end{array}$ \\
\hline \multicolumn{2}{|c|}{ Cooperation among Students } \\
\hline $\begin{array}{l}\text { tCAS1 I ask students to tell each other about their interests } \\
\text { and backgrounds. }\end{array}$ & sCAS1 I try to get to know my classmates. \\
\hline $\begin{array}{l}\text { tCAS2 I encourage my students to prepare together for } \\
\text { classes or exams. }\end{array}$ & sCAS2 I study with other students in my courses. \\
\hline $\begin{array}{l}\text { tCAS4 I ask my students to explain difficult ideas to each } \\
\text { other. }\end{array}$ & sCAS4 I assist other students when I they ask me for help. \\
\hline $\begin{array}{l}\text { tCAS5 I encourage my students to praise each other for their } \\
\text { accomplishments. }\end{array}$ & sCAS5 I tell other students when they have done good work. \\
\hline \multicolumn{2}{|c|}{ Active Learning } \\
\hline $\begin{array}{l}\text { tAL2 I ask my students to summarize similarities and } \\
\text { differences among different mathematical methods. }\end{array}$ & $\begin{array}{l}\text { sAL2 I question the assumptions of the materials in my } \\
\text { courses. }\end{array}$ \\
\hline $\begin{array}{l}\text { tAL3 I ask my students to relate outside events or activities } \\
\text { to the topics covered in my courses. }\end{array}$ & $\begin{array}{l}\text { sAL3 I try to relate outside events or activities to the subject } \\
\text { covered in my courses. }\end{array}$ \\
\hline $\begin{array}{l}\text { tAL4 I give my students concrete, real-life situations to } \\
\text { analyze. }\end{array}$ & $\begin{array}{l}\text { sAL4 I seek real world experiences to supplement my } \\
\text { courses. }\end{array}$ \\
\hline \multicolumn{2}{|c|}{ Prompt Feedback } \\
\hline $\begin{array}{l}\text { tPF5 I give my students written comments on their strengths } \\
\text { and weaknesses on exams and papers. }\end{array}$ & $\begin{array}{l}\text { sPF1 When I get feedback from my professors on exams, } \\
\text { papers, or other class work, I review their responses to assess } \\
\text { my strengths and weaknesses. }\end{array}$ \\
\hline $\begin{array}{l}\text { tPF4 I ask my students to schedule conferences with me to } \\
\text { discuss their progress. }\end{array}$ & $\begin{array}{l}\text { sPF2 I talk over feedback with my professors as soon as } \\
\text { possible if anything is not clear. }\end{array}$ \\
\hline \multicolumn{2}{|c|}{ Time Management } \\
\hline $\begin{array}{l}\text { tTM1 I expect my students to complete their assignments } \\
\text { promptly. }\end{array}$ & sTM1 I complete my assignments promptly. \\
\hline $\begin{array}{l}\text { tTM2 I underscore the importance of regular work, steady } \\
\text { application, sound self-pacing, and scheduling. }\end{array}$ & $\begin{array}{l}\text { sTM4 I maintain a regular study schedule to keep up with } \\
\text { my classes. }\end{array}$ \\
\hline $\begin{array}{l}\text { tTM3 I explain to my students the consequences of non- } \\
\text { attendance. }\end{array}$ & sTM5 I attend class on a regular basis. \\
\hline $\begin{array}{l}\text { tTM5 I meet with students who fall behind to discuss their } \\
\text { study habits, schedules, and other commitments. }\end{array}$ & $\begin{array}{l}\text { sTM6 I confer with my professor if I am concerned about } \\
\text { keeping up with a particular class. }\end{array}$ \\
\hline \multicolumn{2}{|c|}{$\begin{array}{ll}\text { High Expectations } \\
\end{array}$} \\
\hline $\begin{array}{l}\text { tHE2 I emphasize the importance of holding high standards } \\
\text { for academic achievement. }\end{array}$ & $\begin{array}{l}\text { sHE5 I consciously think about the trade-offs between the } \\
\text { things I do to learn and the things I do to achieve a grade. }\end{array}$ \\
\hline $\begin{array}{l}\text { tHE3 I make clear my expectations orally and in writing at } \\
\text { the beginning of each course. }\end{array}$ & $\begin{array}{l}\text { sHE2 I try to get clear information about my instructors' } \\
\text { goals. }\end{array}$ \\
\hline \multicolumn{2}{|c|}{ Respect Diversity } \\
\hline $\begin{array}{l}\text { tRD2 I discourage snide remarks, sarcasm, kidding, and } \\
\text { other behaviors that embarrass other students. }\end{array}$ & sRD1 I try not to embarrass other students \\
\hline $\begin{array}{l}\text { tRD3 I use diverse teaching activities to address a broad } \\
\text { spectrum of students. }\end{array}$ & $\begin{array}{l}\text { sRD2 I consciously adjust my learning habits to } \\
\text { accommodate the teaching practices of my professors. }\end{array}$ \\
\hline $\begin{array}{l}\text { tRD4 I integrate new knowledge about underrepresented } \\
\text { populations into my courses. }\end{array}$ & $\begin{array}{l}\text { sRD5 I support my professors when they include the content } \\
\text { of their courses the contributions or interests of } \\
\text { underrepresened populations. }\end{array}$ \\
\hline
\end{tabular}

Note. Oberst provided permission to reprint. 